\title{
Gender, risk-taking and entrepreneurial intentions: assessing the impact of higher education longitudinally
}

\author{
Eda Gurel \\ Tourism and Hotel Management Department, Bilkent University, Ankara, Turkey \\ Melih Madanoglu \\ Kennesaw State University, Kennesaw, Georgia, USA, and \\ Levent Altinay \\ Oxford Brookes University, Oxford, UK
}

\begin{abstract}
Purpose - This longitudinal study assesses whether higher education has the same impact on the entrepreneurial intentions of women and men with regard to their propensity to risk-taking in particular.

Design/methodology/approach - A self-administrated survey instrument was used to collect data from students studying business and engineering at five selected universities in Turkey. The survey was carried out in two intervals: first year and fourth year of studies. A total of 215 student participated in both waves.

Findings - The findings indicate that the impact of education is stronger for women than for men as the relationship between gender and entrepreneurial intention is moderated by education and risk-taking propensity in that the entrepreneurial intention of women with high or low risk-taking propensity increases when they acquire higher education. In particular, the boost is more noticeable for women with low risk-taking propensity. On the contrary, the effect of education is negative for men with both high risk-taking propensity and low risk-taking propensity.

Practical implications - This study has identified that the impact of education is different for women and men. Based on these findings, Turkey could offer gender-specific entrepreneurship education in higher education for individuals who could then exploit their entrepreneurial capacity and thus contribute to the social and economic well-being of the country.

Originality/value - This paper makes two distinct contributions. First, this is one of the few longitudinal studies in the literature which demonstrates the differences between females and males in terms of their entrepreneurial intention and shows how risk-taking and education influence entrepreneurial intention. Second, it offers new insights into entrepreneurship research from a developing-country but emergingeconomy context.
\end{abstract}

Keywords Entrepreneurial intention, Gender, Risk-taking, Higher education, Longitudinal study

Paper type Research paper

\section{Introduction}

Mostly grounded in the human capital theory, previous research suggests that education influences individuals' levels of entrepreneurship. Researchers such as Casson (1991) and Martin et al. (2013) claim that the transferable skills that individuals develop during their higher education play a significant role in establishing the characteristics generally associated with entrepreneurial behaviour. Others such as Jones and English (2004) argue that some people are born entrepreneurs and education cannot provide business success for those who lack entrepreneurial spirit. Still others, such as Laukkanen (2000), assert that

The authors acknowledge the valuable contributions of Associate Professor Ayşe Baş Collins in the development of the questionnaire. The authors would also like to thank the two anonymous reviewers for their valuable comments.

Received 30 August 2019 Revised 5 April 2020 23 December 2020

5 March 2021

Accepted 16 March 2021 risk-taking, and EI 
formal education decreases the desire to start a new venture. These contradictory findings suggest that the impact of higher education on entrepreneurial intentions merits further study.

The studies mentioned above make an important contribution to the literature on entrepreneurship by investigating the influence of education on entrepreneurship. However, these studies have not investigated the impact of higher education and whether it affects men and women in the same fashion. With the exception of the study conducted by Joensuu $\mathrm{et} \mathrm{al}$. (2013), there is scarce research evidence on the development of entrepreneurial intention in higher education and the effect of gender. As these researchers point out, "instead of general impact of higher education, more effort has been put towards understanding the effects of entrepreneurship education in particular" (Joensuu et al., 2013, p. 784). Therefore, it is not yet known when higher education enhances or reduces entrepreneurial intention, and what role gender plays in this.

The intention of launching a venture is influenced by personality traits such as risk-taking propensity, which is referred to as the "hallmark of the entrepreneurial personality" (quoted in Zhao et al., 2010, p. 388). Previous studies show that even if women have the same level of expertise and experience, they are less likely to take risks than men are (e.g. Dwyer et al., 2002; Harris et al., 2006; Olsen and Cox, 2001). Thus, the effect of the issue of education and gender on entrepreneurial intentions is further exacerbated. That is, there exists a need to consider all three factors in their influence on the intention to start up a business. Therefore, the primary focus of this longitudinal research is to investigate the role of gender in higher education. More specifically, we ask the following question: Does higher education have the same impact on the entrepreneurial intentions of women and men with regard to their propensity to take risk in particular?

To answer our research question, we conducted longitudinal research involving university students in Turkey. The study was undertaken in Turkey because, as a key element in securing competitiveness in international markets and gaining economic growth, entrepreneurship is even more important for developing countries (UNCTAD, 2004) and there is a pressing need to investigate how higher education contributes to the development of entrepreneurial intentions (Passaro et al., 2018; Pfeifer et al., 2016). However, Díaz-García and Jiménez-Moreno lamented that "most of our understanding of the entrepreneur derives from research done in Anglo-Saxon countries, and it is unclear how applicable these findings to other countries" (2010, p. 263).

This paper makes two distinct contributions to the literature. First, this is one of the few longitudinal studies that aims to demonstrate the differences between females and males in terms of entrepreneurial intention and how risk-taking propensity and higher education influence their entrepreneurial intentions. Second, this study offers new insights into entrepreneurship research in the context of a developing country with an emerging economy, Turkey, where entrepreneurship education is still in its infancy.

\section{Conceptual model and hypotheses}

Pillis and Reardon (2007, p. 383) define entrepreneurial intention as "the intention to start a new business". In line with the well-known intentions models of Ajzen (1985) and Shapero and Sokol (1982), Learned (1992) proposed an organisation formation model with a number of dimensions which interact and provide the potential for an individual to found an organisation. According to his model, although individuals may have the necessary combination of traits and background referred to as person-level variables, the actual decision to found arises from the interaction of the potential with the situation. Consequently, Learned (1992, p. 42) proposed that "intentionality is a function of dispositional, background, and situational factors, and their interactions". Recognising the importance of situational factors 
in the start-up process, Frank et al. (2007) also claimed that personality traits may change as a result of the interaction between natural (psychogenetic) and environmental (learning behaviour) factors. Accordingly, we propose the conceptual model in Figure 1 and aim to test the three-way interaction of gender, risk-taking propensity and higher education on entrepreneurial intentions. More specifically, we aim to test whether an individual who has a high risk-taking propensity would be becoming intentional as they approach graduation from the university. In doing so, we also aim to test the role of gender since it is neglected in most research studies as pointed out by researchers such as Díaz-García and Jiménez-Moreno (2010), Shinnar et al. (2014) and Wilson et al. (2007). Investigating gender differences in entrepreneurship intentions, this paper builds upon the studies of Haus et al. (2013) and Joensuu et al. (2013). In the following section, we present the hypotheses of the study in line with our conceptual model.

\section{Gender differences in entrepreneurial intention}

In their systematic literature review on entrepreneurial intentions, Linan and Fayolle (2015) found that males exhibit a more positive attitude towards entrepreneurship, and therefore have higher entrepreneurial intention. However, these results need further explanation, as "many of the studies simply state the facts, with no in-depth consideration of the reasons for this gap" (Zeffane, 2015, p. 223). Still, researchers assert that such differences are caused by gender stereotypes (Gupta et al., 2008) and gender-specific barriers (Verheul et al., 2012). Based on available research findings and labour market data sets, Shane (2008, p. 134) concludes that an individual's gender "is one of the best predictors we have of who will become an entrepreneur". Therefore, we hypothesise:

H1. Females will be less inclined to become entrepreneurs relative to males.

\section{Risk-taking propensity and entrepreneurial intention}

In the earliest discussions, a number of studies (e.g. Brockhaus, 1980; Carland et al., 1988; Thomas and Muller, 2000) have examined the existence of certain personality traits or characteristics believed to characterise entrepreneurs. In this regard, several researchers (Davidsson, 1995; McClelland, 1961) argue that some personality traits define entrepreneurs and motivate entrepreneurial behaviour. For instance, McClelland (1961) indicated that traits which define entrepreneurial behaviour are high need for achievement, a moderate risktaking propensity and the readiness to assume personal responsibility for successes or failure, among others. Similarly, Stewart et al. (1999) found need for achievement, risk-taking propensity and innovation as the determinants for distinguishing entrepreneurs from other business operators. More recently, in a meta-analysis on personality traits on intention, Zhao et al. (2010) analysed the effects of the big five personality dimensions, and found that all

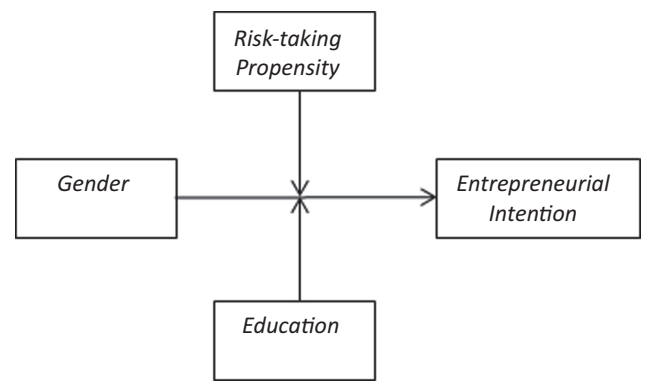

Figure 1. Conceptual model 
ET

63,5

factors predict intention, with risk propensity acting as the best predictor. Propensity to take risk refers to how likely it is that an individual will exhibit risk-taking or risk avoidance when confronted with risky situations (Gürol and Atsan, 2006). Particularly, studies involving student samples (Ertuna and Gurel, 2011; Gurel et al., 2010; Gürol and Atsan, 2006; Koh, 1996) show that entrepreneurially disposed students have significantly higher scores in risk-taking than non-entrepreneurially disposed students. Therefore, we hypothesise:

H2. Risk-taking propensity is positively related to entrepreneurial intention.

\section{Gender differences in risk-taking propensity}

There is extensive evidence in literature that females are less likely to take risks than males (e.g. Byrnes et al., 1999; Harris et al., 2006; Johnson and Powell, 1994) even if they have the same level of expertise and experience (e.g. Dwyer et al., 2002; Harris et al., 2006; Olsen and Cox, 2001). Using a large data from a national survey of investors, Dwyer et al. (2002) investigated whether gender is related to risk-taking in mutual fund investment decisions of investors, and found that women display less risk-taking decision-making than men in their largest and riskiest mutual fund investments. They argue that the greater level of risk aversion among women may be explained by knowledge disparities between women and men. Slovic (2000, p. xxxiv) concluded that, "Almost every study on risk perception has found that men seem to be less concerned about hazards than are women". Although there is evidence that women are more risk-averse than men, the reasons for the disparities are not fully empirically explained (Zeffane, 2015). Zeffane (2015) claimed that when investigating the reasons behind gender differences in entrepreneurial intentions, gender differences in the propensity to risk-taking appear to be a significant exploratory variable. Therefore, based on the above discussions, we hypothesise:

H3. Males with high risk-taking propensity are more likely to engage in entrepreneurship than females with high risk-taking propensity.

\section{Gender differences in higher education}

When investigating the relationships between gender, risk-taking propensity and intention, other individual dimensions that could affect these variables need to be included. Applying the contingency perspective to entrepreneurship with our conceptual model, we argue that education will act as a situational variable in the relationship between gender, risk-taking propensity and entrepreneurial intentions. However, research findings on the impact of higher education on entrepreneurial intentions remain inconclusive. While some researchers contend that education reduces the desire and skills for creating a new business venture among individuals (Joensuu et al., 2013; Wu and Wu, 2008), others argue that individuals' entrepreneurial intentions increase with education (Davidsson, 1989; Ertuna and Gurel, 2011). Grounded in human capital theory, in their meta-analysis of 73 studies and 37,285 individuals, Bae et al. (2014) predicted that education will directly influence students' entrepreneurial intention, although they found a small but significant relationship between education and intention, with entrepreneurial education significantly more strongly associated with intention than general business education. Therefore, we hypothesise:

H4. There is positive relationship between education and entrepreneurial intention.

Extant literature indicates that there are a number of moderators that significantly increase the impact of education on intentions; among those are national culture in group cohesion, lower uncertainty avoidance and gender egalitarianism. Indeed, in literature regarding higher education, a specific line of research focuses on the entrepreneurship gender gap (Bae et al., 2014). While some studies (e.g. Rubio et al., 1999; Shay and Terjensen, 2005; 
Wilson et al., 2004) indicate that a lower percentage of women considered founding their own company, others found no significant differences between male and female students regarding entrepreneurial intentions (e.g. Gonzales, 2001; Shinnar et al., 2009). However, Canizares and Garcia (2010) claimed that the entrepreneurship gender gap still remains in higher education.

In order to identify the reasons behind this gender gap, Wasylow et al. (2006) focused on educational background and point out that while the majority of male students study technical and experimental sciences, which offer possibilities for self-employment, female students choose to study social and health majors which are more oriented to work for others. Canizares and Garcia (2010, p. 779) concluded that women are less likely to set up a company due to fear of failure. The attributes associated with a greater intention to start a business also differ by gender. "While female students associate initiative and creativity with entrepreneurship, male students attach greater importance to factors such as the desire for new challenges or the willingness to take moderate risks". Accordingly, Canizares and Garcia (2010) suggest taking into account gender differences in perceptions and entrepreneurial culture when designing programmes to promote entrepreneurship in higher education. Leroy et al. (2009) also investigated gender effects on entrepreneurial intention and found important gender differences in the factors that shape entrepreneurial intentions among Belgian undergraduates. They found that while men prefer entrepreneurship as a means of getting ahead, and consider financial constraints and creativity in making the decision to become an entrepreneur, women prefer entrepreneurship as a means of getting organised, and consider personal capabilities and knowledge in their decision to become an entrepreneur. Because the motivations which drive male and female entrepreneurs seem to be different, these authors suggest that men and women should be treated differently when stimulating or raising their entrepreneurial intention. Stimulating female entrepreneurship may require training in different competencies than those typically associated with male-dominated entrepreneurship (as cited in Sivarajah and Achchuthan, 2013).

Given the gender differences in entrepreneurial intentions, risk-taking and higher education suggested by the literature, in line with our conceptual model, we are motivated to test the three-way interaction of gender, risk-taking and higher education on entrepreneurial intentions with the following hypothesis:

H5. The relationship between gender and entrepreneurial intention is moderated by education and risk-taking propensity.

\section{Methodology}

Sample and procedure

For this study, data were collected from undergraduate students studying business administration and industrial engineering at three public and two private universities in Turkey. [For the purposes of anonymity and ethics the names of the universities are not revealed.] Although the participating universities represented a convenience sample, all of them are ranked in the top 20 universities by the Times Higher Education in Turkey (QS World University Rankings, 2020).

Following Fayolle and Linan (2014), pre- and post-intervention designs were used. In the first phase of the research, a total of 553 useable questionnaires were collected from first-year students during classes in the first month of their studies (Time 1). This was done either under the monitoring of one of the authors or with the guidance of the university professors. The questionnaires were collected from the students who were in class on the day they were handed out and participation was voluntary and anonymous. Due to the longitudinal nature of the study, students were requested to write the last three letters of their names and surnames to protect their anonymity. A second wave of the questionnaire was disseminated 
ET

63,5

\section{2}

four years later to the same sample of students in their final year just before their final examinations (Time 2) in the university. These surveys were administered during class time as in Time 1. Therefore, in this longitudinal study, the same sample of students was contacted across the course of their undergraduate studies. The second wave of the survey administration elicited 445 responses from the final-year students. The students who did not indicate their names and departments and the students who were not able to be matched based on their names were eliminated. In addition, we eliminated those students who were not involved in the initial sample (students who were in their third or fifth year at the university; 150 students) but were present in the classrooms on that day. As a result, the final sample included 215 useable survey pairs. Some attrition occurred between the administration of the first and second surveys since some students were absent on the day that the second survey was administered.

Attrition bias is a common problem in longitudinal studies as there may be many nonrespondents in subsequent waves, which may threaten external validity when findings may not be generalised to other populations (Gustavson et al., 2012). As noted before, the baseline data collection had 558 respondents. As the second wave of data collection was almost four years later, it is plausible that many students $(N=338)$ would drop out of the sample for a variety of reasons such as failing in some courses, changing majors, transferring to another university and family or health reasons. While it is not possible to observe reasons for dropping out of the study (after the freshmen year), we used our main model as a predictor of attrition in a logistic regression model to check for attrition bias. In that model, students who dropped out of the sample in Year 1 were coded as one, and zero otherwise. The results are reported in odds ratios. As can be seen in Table 1, Model 1 includes demographic variables and shows that males relative to females were more likely to drop out of the sample. However, the inclusion of personality traits (Model 2) changed the results and indicated that none of the variables is significantly related to attrition. Therefore, we conclude that attrition is a random pattern and, thus, our results are not subject to attrition bias.

We took an extra precautionary step to increase the confidence in our findings by conducting additional analysis with students who responded in the second wave but were not present in Year $1(N=80)$. We created a dummy predictor variable where respondents of the second wave were coded as one, while participants in both waves $(N=215)$ were coded as zero. We conducted a basic logistic regression model where entrepreneurial intention was used as an outcome variable. Findings revealed that joining the study later did not have a

\begin{tabular}{lcr}
\hline Variable & Model 1 & Model 2 \\
\hline Family background & 0.869 & 0.858 \\
First born child & 1.072 & 1.092 \\
Female (gender) & $0.693^{*}$ & 0.736 \\
Private university & 1.214 & 1.157 \\
Locus of control & & 0.929 \\
Tolerance of ambiguity & & 1.114 \\
Innovativeness & & 1.079 \\
Independence & & 0.843 \\
Risk-taking propensity & Yes & 1.249 \\
Department dummies & 5.842 & Yes \\
Constant & -349.981 & 4.319 \\
Log pseudo-likelihood & 29.67 & -347.894 \\
Wald $\chi^{2}$ & & 34.79 \\
Note(s): $* p<0.05$ & & \\
& &
\end{tabular}

Table 1.

Predicting attrition with demographic and personality trait variables 
significant relationship with entrepreneurial intention. Thus, we conjecture that students who participated in repeated measures $(N=215)$ do not present a sample bias when it comes to predicting entrepreneurial intention.

\section{Gender, risk-taking, and EI}

\section{Questionnaire development and measurement}

A self-administered survey instrument was used to collect data from students. The main items of the instrument were adapted from well-established scales and were then translated into Turkish. In order to test the accuracy of the translated instruments, pre-tests were carried out.

\section{Dependent variable}

In order to measure entrepreneurial intention, respondents were asked whether or not they intended to establish their own businesses. This is a dichotomous variable where one represents students with entrepreneurial intention and zero represents students with no entrepreneurial intention. Similar measures have been used in previous research investigating entrepreneurial intentions (e.g. Canizares and Garcia, 2010) and entrepreneurial success (e.g. Frank et al., 2007).

\section{Independent and moderating variables}

In this study, gender, risk-taking propensity and education were employed as predictors of entrepreneurial intention. Gender was our key independent variable as in the studies of Haus et al. (2013) and Joensuu et al. (2013). It is a binary variable where females were coded as one, and males were coded as zero. Risk-taking propensity is our first moderator and was assessed by the Jackson Personality Inventory (JPI) manual - revised edition (Jackson, 2007). This scale has four components including monetary, physical, social and ethical risk-taking. The study used 10 items related to monetary and social risk-taking. A high score on this indicates that the respondent enjoys gambling, taking chances and adventure, and is unconcerned with danger (Sexton and Bowman-Upton, 1990). The instrument has been used in a number of research studies (Ertuna and Gurel, 2011; Gurel et al., 2010; Stewart et al., 1999). It was measured using a five-point Likert scale between one (strongly disagree) and five (strongly agree). To minimise response-set bias and the halo effect, some statements were reversescored and intermingled with other statements. Besides risk-taking propensity, education is introduced as a moderating variable, where zero represents students with less education (first-year, freshmen students) and one represents students with more education (fourth-year, seniors students).

\section{Control variables}

A select group of personality traits such as innovativeness, tolerance for ambiguity, need for achievement and items measuring common socio-cultural factors that predispose individuals to act entrepreneurially were included as control variables. All items were measured using a five-point Likert scale ranging from one (strongly disagree) to five (strongly agree).

In order to measure innovativeness, eight items from the JPI manual were used, as employed by Mueller and Thomas (2001). Four items adapted by Acedo and Jones (2007) were used to test tolerance for ambiguity. In order to measure internal locus of control, a modified version of Rotter's I-E Scale as employed by Mueller and Thomas (2001) and consisting of 10 items was used. Finally, to measure need for achievement, we adopted three items from Kahl's (1965) achievement values which capture the independence dimension of that construct.

Based on previous research findings, birth order (Koh, 1996; Webber, 2007) and family background (Altinay et al., 2012; Canizares and Garcia, 2010; Sullivan and Meek, 2012) were 
included as control variables, as these studies have shown that first-born children and individuals with entrepreneurial families have higher propensities to establish their own businesses. In addition, the subject of the study (i.e. major) and the type of university (public vs private) were included as other control variables.

\section{Reliabilities of scales}

Findings show that risk-taking propensity had a Cronbach's alpha coefficient of 0.70 , innovativeness had a value of 0.78 , locus of control had a coefficient of 0.75 , tolerance of ambiguity had a value of 0.73 and independence had a value of 0.64 . With the exception of independence, these values are considered to have acceptable reliability because they exceed the cut-off value of 0.70 (Hair et al., 1998).

\section{Statistical procedures}

Since the dependent variable in this study is dichotomous, we used random-effects logistic regression $x$ tlogit in Stata15. The first model in this study (Model 1) uses the control variables and the three independent variables (gender, education and risk-taking propensity) to test $\mathrm{H} 1, \mathrm{H} 2$ and H4. Model 2 extends Model 1 by adding the interaction term of gender and risk-taking propensity to test H3. Model 3 is the augmented version of Model 1, where the three-way interaction term of gender, risk-taking and education is the focal variable in testing H5 (see Table 4).

\section{Results and discussion}

Descriptive statistics indicate that more than $40 \%$ of students were part of a family that had some business background (see Table 2). In addition, approximately $46 \%$ of students were first-born children. Among personality traits, independence had the highest mean (3.923), while tolerance of ambiguity had the lowest average (2.511). We analysed correlations, particularly those among personality traits, to ensure that our findings are not borne by multicollinearity. Results show that personality traits did not have high intercorrelations, which leads us to conclude that multicollinearity is not an issue in our analysis.

Next, we conducted a two-sample $t$-test analysis to assess whether higher education led to some changes in personality traits and entrepreneurial intention over time. Findings show that locus of control decreased over time (3.510 vs $3.375, p<0.01)$ (see Table 3$)$. On the

\begin{tabular}{|c|c|c|c|c|c|c|c|c|c|c|}
\hline Variable & Mean & $\mathrm{SD}$ & 1 & 2 & 3 & 4 & 5 & 6 & 7 & 8 \\
\hline 1. Locus of control & 3.444 & 0.922 & 1 & & & & & & & \\
\hline $\begin{array}{l}\text { 2. Tolerance of } \\
\text { ambiguity }\end{array}$ & 2.511 & 0.922 & $0.187^{*}$ & 1 & & & & & & \\
\hline 3. Innovativeness & 3.531 & 0.558 & $0.182^{*}$ & $0.321^{*}$ & 1 & & & & & \\
\hline 4. Independence & 3.923 & 0.753 & $0.250 *$ & 0.066 & $0.216^{*}$ & 1 & & & & \\
\hline $\begin{array}{l}\text { 5. Risk-taking } \\
\text { propensity }\end{array}$ & 3.114 & 0.550 & $0.193^{*}$ & $0.338^{*}$ & $0.323^{*}$ & $0.211 *$ & 1 & & & \\
\hline $\begin{array}{l}\text { 6. Family } \\
\text { background }\end{array}$ & 0.432 & 0.496 & 0.032 & 0.105 & -0.004 & -0.046 & 0.086 & 1 & & \\
\hline 7. First-born & 0.460 & 0.499 & 0.051 & 0.028 & 0.002 & 0.070 & -0.007 & 0.022 & 1 & \\
\hline 8. Entrepreneurial & 0.467 & 0.499 & 0.096 & $0.146^{*}$ & $0.289 *$ & 0.059 & 0.303 & $0.179 *$ & 0.022 & 1 \\
\hline
\end{tabular}

Table 2.

Descriptive statistics
Note(s): SD = Standard deviation; ${ }^{*} p<0.05$. Relationships between continuous variables are covariances: Relationships between binary variables are tetrachoric correlations 
contrary, tolerance of ambiguity increased as individuals acquired higher education (2.405 vs $2.616, p<0.05)$. All other variables, including entrepreneurial intention, remained statistically identical to their pre-education values.

Our main analysis shows that among control variables, family background and innovativeness were positively related to entrepreneurial intention $(0.738, p<0.05$ and 0.961 , $p<0.01$ respectively) (see Table 4). Findings reveal that, overall, females were less likely to engage in entrepreneurship $(-1.157, p<0.01)$, which lends support for H1. This finding is in line with previous research (Dwyer et al., 2002; Harris et al., 2006; Olsen and Cox, 2001) that demonstrated noticeable gender differences in terms of entrepreneurship and/or engagement with entrepreneurial activities. It is also worth noting that risk-taking propensity was positively related to entrepreneurial intention $(1.141, p<0.01)$, which is consistent with the predictions of $\mathrm{H} 2$. Model 2 investigates the moderating effect of risk-taking propensity on the relationship between gender and entrepreneurial intention. Results show that the interaction term of gender and risk-taking propensity does not have a significant effect on entrepreneurial intention. Thus, H3 is not supported. Next, we test whether acquisition of a higher education degree increases entrepreneurial intention (see Model 1 in Table 4).

\begin{tabular}{lccr}
\hline & \multicolumn{2}{c}{ Mean score (SD) } & \\
Variable & Freshmen & Senior & $t$-value \\
\hline Locus of control & $3.510(0.469)$ & $3.375(0.502)$ & $2.816^{* *}$ \\
Tolerance of ambiguity & $2.405(0.975)$ & $2.616(0.856)$ & $-2.358^{*}$ \\
Innovativeness & $3.506(0.551)$ & $3.556(0.039)$ & -0.916 \\
Independence & $3.898(0.724)$ & $3.949(0.782)$ & -0.690 \\
Risk-taking propensity & $3.159(0.561)$ & $3.260(0.611)$ & -1.151 \\
Entrepreneurial intention & $0.437(0.497)$ & $0.497(0.501)$ & -1.255 \\
Note(s): ${ }^{*} p<0.05 ; * p<0.01 ; * * p<0.001$ & &
\end{tabular}

Gender, risk-taking, and EI

785

Table 3.

Summary $t$-test results comparing freshmen and senior students

\begin{tabular}{|c|c|c|c|c|}
\hline Variable & Model 1 & Model 2 & Model 3 & \\
\hline Family background & $0.738^{*}$ & $0.742^{*}$ & $0.178 * * *$ & \\
\hline First born child & 0.327 & 0.338 & $0.807^{*}$ & \\
\hline Female (gender) & $-1.157 * *$ & $-1.142^{* *}$ & $-1.096^{* * *}$ & \\
\hline Private university & 0.112 & 0.097 & 0.103 & \\
\hline Locus of control & -0.001 & -0.056 & -0.035 & \\
\hline Tolerance of ambiguity & -0.021 & -0.004 & -0.035 & \\
\hline Innovativeness & $0.961 * *$ & $0.973^{* *}$ & $0.990 * *$ & \\
\hline Independence & -0.090 & -0.067 & -0.073 & \\
\hline Risk-taking propensity & $1.141^{* *}$ & 0.806 & $1.467 *$ & \\
\hline Education & 0.170 & 0.179 & 0.293 & \\
\hline Risk-taking propensity $*$ Gender & & 0.655 & -0.612 & \\
\hline Risk-taking propensity $*$ Education & & & -1.154 & \\
\hline Gender * Education & & & 0.216 & \\
\hline Risk-taking propensity $*$ Gender $*$ Education & & & $2.600 *$ & \\
\hline Major dummies & Yes & Yes & Yes & Table 4. \\
\hline Constant & $-6.657 * *$ & $-5.748^{* *}$ & $-2.779 * *$ & The influence of risk- \\
\hline Log likelihood & -222.555 & -221.927 & -219.394 & gender and education \\
\hline Wald $\chi^{2}$ & 38.76 & 40.24 & 39.61 & on entrepreneurial \\
\hline $\operatorname{Note}(\mathbf{s}):{ }^{*} p<0.05 ; * * p<0.01 ; * * * p<0.001$ & & & & intention \\
\hline
\end{tabular}


ET

63,5

\section{6}

Figure 2.

The three-way interaction of gender, risk-taking propensity and education
Results reveal that the relationship between education and entrepreneurial intention is not significant $(0.170, p>0.05)$ and, thus $\mathrm{H} 4$ is not supported.

Model 3 looks at the effect of the three-way interaction of gender, risk-taking propensity and education on entrepreneurship (see Table 4). Results reveal that the three-way interaction is positively related to entrepreneurial intention $(2.600, p<0.05)$. To ease the interpretation of this effect, we plotted values for the three variables in Figure 2. As can be seen in Figure 2, we are able to ascertain that, among individuals with high risk-taking propensity, education leads to a modest increase in entrepreneurial intention for females, while it leads to a decrease in entrepreneurial intention among males. Among individuals with low-risk-taking propensity, education has a reversal effect for females relative to males. That is, females with low risk-taking propensity become more inclined to pursue entrepreneurial activities as they acquire their higher education degrees. On the contrary, males with low risk-taking propensity become less interested in entrepreneurship as they further their education. Taken together, these observations offer support for $\mathrm{H} 5$ which predicts that risk-taking would have a differential effect on entrepreneurial intention for females vs. males with higher education.

This is an important finding which adds to the existing body of knowledge about the differences between women and men in terms of their risk-taking propensity and entrepreneurial intention, and the influence of education on entrepreneurship. In contrast to the existing literature (Leroy et al., 2009), the findings of this study demonstrate that females with low risk-taking propensity who acquire higher education have an increased desire to engage in entrepreneurial activities relative to males who acquired higher education and have low risk-taking propensity. It is worth emphasising that females with low risktaking propensity experience a noticeable bump in entrepreneurial intention as they become more educated. This bump pushes females with low risk-taking propensity to a higher level of entrepreneurial intention compared to freshmen and senior males with low risk-taking propensity (see Figure 2). We interpret this as education acting as a substitute for risk-taking propensity. In other words, females who have low risk-taking propensity feel more confident in undertaking entrepreneurial activities in the future once they acquire their undergraduate degrees. On the contrary, males with low risk-taking propensity encountered the opposite effect of education as their entrepreneurial intention dropped after receiving undergraduate education. This result supports the studies of Wilson et al. (2007) and Sullivan and Meek (2012) who argued that education could equip women with the belief that they have the abilities to successfully pursue entrepreneurial opportunities.

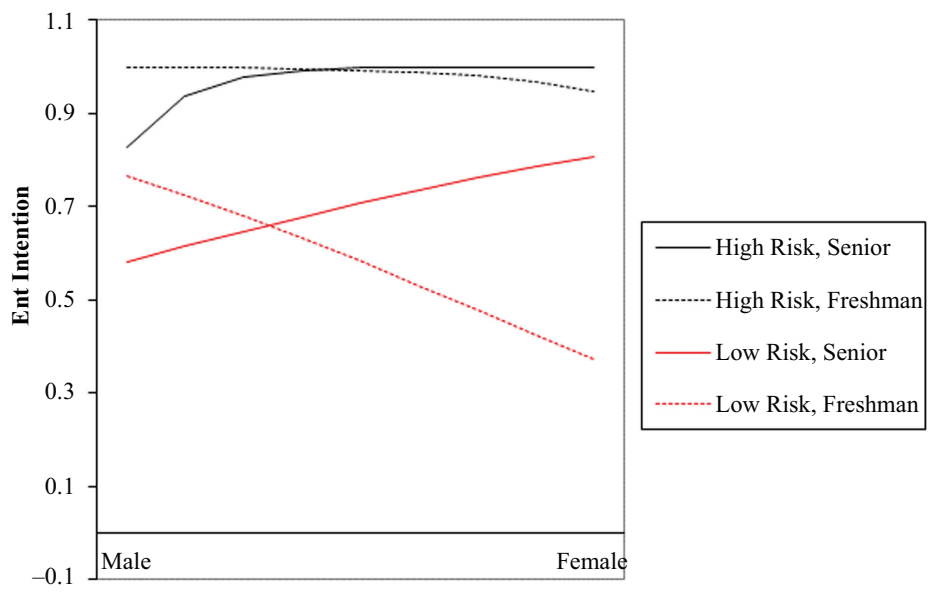




\section{Conclusions}

\section{Contributions}

This study makes two distinct contributions. Firstly, this is one of the few longitudinal studies in the literature which demonstrates the differences between females and males in terms of their entrepreneurial intention, as well as how risk-taking propensity and education influence their entrepreneurial intentions.

Findings of this study demonstrate a gender difference in how intentions develop with risk-taking propensity and education over time. Male students have a higher initial level to start up a business, but their intentions do not increase as they come close to graduation; on the other hand, females experience some intention boost as they advance in their studies. More interestingly, differences are observed within gender rather than across gender depending on risk-taking propensity. That is, males with high risk-taking propensity experience a drop in their entrepreneurial intentions once they are about to complete their formal university education. Moreover, the effects of higher education on entrepreneurial intentions proved stronger for women than men depending on their levels of risk-taking propensity. In particular, females with low risk-taking propensity benefitted the most from education as it comes to increasing their probability to engage in entrepreneurship.

These findings support earlier research conducted by Shinnar et al. (2014) on entrepreneurial self-efficacy and entrepreneurship education. Hence, gender differences are evident not only in entrepreneurship education but also in higher education. In line with our conceptual model, these findings provide more evidence supporting the notion that gender must be integrated into any study of education and entrepreneurial intentions. Since most studies include gender as just another demographic or control variable when studying entrepreneurship, our findings shed some light on the reason why previous studies obtained mixed findings on the impact of education. That is, this may be due to the neglected role of gender and levels of risk-taking propensity within genders.

Specific to entrepreneurship education, Wilson et al. (2007) found that entrepreneurial education is more positively related to the entrepreneurial self-efficacy of women than of men. Their findings strongly support the importance of well-designed education in developing the entrepreneurial intentions of women. In this regard, our research contributes new understating of the value of higher education for women with both low and high risktaking propensity. With the acquisition of higher education, women may feel they have what it takes to be successful in starting their own business (Wilson et al., 2007) even if they have low risk-taking propensity. In particular, our study goes further than the existing research by concluding that intention development in the higher education context is not a simple matter. Rather, it is a complicated process as the impact of education is different on women and men with low and high risk-taking propensity which has a bearing on their entrepreneurial intentions. Higher education seems to make more of a positive difference for women with low risk-taking propensity, but it does have a negative effect for men with the same level of risktaking propensity.

Second, this study offers new insights into entrepreneurship research from a developingcountry but emerging-economy context. Our empirical observations clearly demonstrate a gender difference in both initial level of intentions and the way in which intentions evolve over time depending on an individual's risk-taking propensity. Given that this study has identified that higher education does not have the same impact on women and men, the importance of Turkey as a developing and emerging country emerges as a context that could offer gender-specific education for female entrepreneurship to foster intentions of potential entrepreneurs. As already suggested by researchers (e.g. Díaz-Garzía and Jiménez-Moreno, 2010; Kassean et al., 2015; Wilson et al., 2007), there is not a "one-approach-fits-all" model of

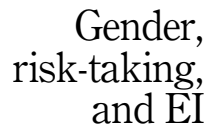


ET

63,5

entrepreneurship education. Gender-sensitive programming may be required by integrating different pedagogical approaches to satisfy the needs of both genders. In this sense, it would be necessary to adjust educational curricula by customising it to the particular needs of both genders in order to improve its effectiveness.

\section{Implications}

These results have a number of implications for academics and policymakers. Generally, entrepreneurship education is in its infancy in developing countries. To cultivate the necessary entrepreneurial activities and the mindset for national competitiveness and economic growth, such countries rely on their higher educational programmes. For instance, in Turkey, entrepreneurship training only began as elective courses in business administration programmes after 1995. Currently, an entrepreneurship course is compulsory in only a handful of universities in the country (Gürol and Atsan, 2006). As of 2020 , only three universities have a dedicated undergraduate major in entrepreneurship (ÖSYM, 2020). In order to provide a strategic framework for the advancement of entrepreneurship - in particular, youth and female entrepreneurship in Turkey - an Entrepreneurship Strategy and Action Plan was introduced in 2015. The plan involves increasing the amount of entrepreneurship programmes in higher education, with the intention of fostering an entrepreneurial mindset in individuals for the promotion of entrepreneurship in Turkey. We suggest that this Strategy and Action Plan is implemented with immediate effect. However, it should be noted that women and men may be benefitting from higher education differently. Therefore, Turkey, as well as the other countries aiming to develop their entrepreneurship capacity, needs to develop gender-specific education to foster entrepreneurial intentions of individuals.

\section{Limitations and future research}

Our methodological contribution is the use of a longitudinal research design. As stated by Johensuu et al. (2013), the development of entrepreneurial intentions has been studied extensively, but the majority of these studied have been cross-sectional. As it is challenging to conduct longitudinal studies, few exist to help us better understand how an individual's intentions develop over time as one pursues their degree in higher education. By using a longitudinal design, this study is one of the first to provide empirical evidence about the intention development over time. Although we believe that the results presented herein add to our understanding of the role of entrepreneurial education in the development of intentions for both women and men in higher education contexts, this study is not free of limitations. First, this study looks at entrepreneurial intention, and, thus, we are not able to verify which participants became actual entrepreneurs. We can only infer conclusions about intention, not action. Second, the context of the study is a major metropolitan area in a developing country. It is plausible that this context may have an influence on entrepreneurial intention. Metro areas may lead to opportunity-driven entrepreneurship, while necessity-driven entrepreneurship may be more prevalent in smaller cities in developing countries. Future studies should use a sample of high-school students from smaller cities in developed and developing countries to expand the validity of the results of this study. It is our hope that future studies take a multi-pronged approach to delve into the entrepreneurship phenomenon by including diverse demographics, multiple countries and varying locations. Future research should also investigate what works and what does not work in education, recognising the different competencies required by women and men. Future efforts to develop appropriate and effective education programmes should consider the complexities presented with the findings of this research. 


\section{References}

Acedo, F.J. and Jones, M.V. (2007), "Speed of internationalization and entrepreneurial cognition: insights and a comparison between international new ventures, exporters and domestic firms", Journal of World Business, Vol. 42, pp. 236-252.

Ajzen, I. (1985), "From intentions to actions: a theory of planned behavior", in Kuhl, J. and Beckhann, J. (Eds), Action Control: From Cognition to Behavior, Springer-Verlag, New York, NY, pp. 11-39.

Altinay, L., Madanoglu, M., Daniele, R. and Lashley, C. (2012), "The influence of family tradition and psychological traits on entrepreneurial intention", International Journal of Hospitality Management, Vol. 31, pp. 489-499.

Bae, T.J., Qian, S., Miao, C. and Fiet, J.O. (2014), "The relationship between entrepreneurship education and entrepreneurial intentions: a meta-analytic review", Entrepreneurial Theory and Practice, Vol. 38 No. 2, pp. 217-254.

Brockhaus, R.H. (1980), "Risk taking propensity of entrepreneurs", in Vesper, K.H. (Ed.), Encyclopaedia of Entrepreneurship, Prentice-Hall, Englewood Cliffs, New Jersey, Academy of Management Journal, Vol. 23 No. 3, p. 509.

Byrnes, J.P., Miller, D.C. and Schafer, W.D. (1999), "Gender differences in risk-taking: a metaanalysis", Psychological Bulletin, Vol. 125 No. 3, pp. 367-383.

Canizares, S.M.S. and Garcia, F.J.F. (2010), "Gender differences in entrepreneurial attributes", Equality, Diversity and Inclusion: International Journal, Vol. 29 No. 8, pp. 766-786.

Carland, J.C., Hoy, F. and Carland, J.A. (1988), "Who is the entrepreneur? Is a question worth asking", American Journal of Small Business, Vol. 12 No. 4, pp. 33-39.

Casson, M.C. (1991), The Entrepreneur: The Economic Theory, Gregg Revivals, London.

Davidsson, P. (1989), Continued Entrepreneurship and Small Firm Business, Stockholm School of Economics, Stockholm.

Davidsson, P. (1995), "Determinants of entrepreneurial intentions", Paper Presented at the RENT IX Workshop, Piacenza, p. 11.

Díaz-García, M. and Jiménez-Moreno, J. (2010), "Entrepreneurial intention: the role of gender", The International Entrepreneurship and Management Journal, Vol. 6, pp. 261-283.

Dwyer, P.D., Gilkeson, J.H. and List, J.A. (2002), "Gender differences in revealed risk-taking: evidence from mutual fund investors", Economics Letters, Vol. 76 No. 2, pp. 151-158.

Ertuna, Z.I. and Gurel, E. (2011), "The moderating role of higher education on entrepreneurship", Education + Training, Vol. 53 No. 5, pp. 387-402.

Fayolle, A. and Linan, F. (2014), "The future of research on entrepreneurial intentions", Journal of Business Research, Vol. 67, pp. 663-666.

Frank, H., Lueger, M. and Korunka, C. (2007), "The significance of personality in business start-up intentions, start-up realization and business success", Entrepreneurship and Regional Development, Vol. 19, pp. 227-251.

Gonzales, M.M.O. (2001), "Actitudes y motivaciones hacia el trabajo y la creación de empresas según género”, Buletin Económico ICE, Vol. 2709, pp. 21-29.

Gupta, V.K., Turban, D.B. and Bhawe, N.M. (2008), "The effect of gender stereotype activation on entrepreneurial intentions", Journal of Applied Psychology, Vol. 93 No. 5, pp. 1053-1061.

Gurel, E., Altinay, L. and Daniele, R. (2010), “Tourism students' entrepreneurial intentions”, Annals of Tourism Research, Vol. 37 No. 3, pp. 646-669.

Gürol, Y. and Atsan, N. (2006), "Entrepreneurial characteristics amongst university students: some insights for entrepreneurship education and training in Turkey”, Education + Training, Vol. 48 No. 1, pp. 25-38.

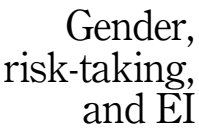

$-$ 
ET

63,5

Gustavson, K., von Soest, T., Karevold, E. and Røysamb, E. (2012), “Attrition and generalizability in longitudinal studies: findings from a 15-year population-based study and a Monte Carlo simulation study", BMC Public Health, Vol. 12 No. 1, p. 918.

Hair, F., Jr, Anderson, R.E., Tatham, R.L. and Black, W.C. (1998), Multivariate Data Analysis with Readings, 5th ed., Prentice-Hall, Upper Saddle River, New Jersey.

Harris, C.R., Jenkins, M. and Glaser, D. (2006), "Gender differences in risk assessment: why do women take fewer risks than men?”, Judgment and Decision Making, Vol. 1 No. 1, pp. 48-63.

Haus, I., Steinmetz, H. and Isidor, R. (2013), "Gender effects on entrepreneurial intention: a metaanalytic structural equation model", International Journal of Gender and Entrepreneurship, Vol. 5 No. 2, pp. 130-156.

Jackson, D. (2007), Jackson Personality Inventory - Revised, Research Psychologists Press, Goshen, New York.

Joensuu, S., Viljamaa, A., Varamäki, E. and Tornikoski, E. (2013), "Development of entrepreneurial intention in higher education and the effect of gender - a latent growth curve analysis", Education + Training, Vol. 55 Nos 8/9, pp. 781-803.

Johnson, J. and Powell, P. (1994), “Decision making, risk and gender: are managers different?”, British Journal of Management, Vol. 5 No. 1, pp. 123-138.

Jones, C. and English, J. (2004), “A contemporary approach to entrepreneurship education”, Education + Training, Vol. 46 Nos 8/9, pp. 416-423.

Kahl, J.A. (1965), "Some measurements of achievement orientation”, American Journal of Psychology, Vol. 70, pp. 669-81.

Kassean, H., Vanevenhoven, J., Liguori, E. and Winkel, D.E. (2015), "Entrepreneurship education: a need for reflection, real-world experience and action", International Journal of Entrepreneurial Behavior and Research, Vol. 21 No. 5, pp. 690-708.

Koh, H.C. (1996), "Testing hypotheses of entrepreneurial characteristics: a study of Hong Kong MBA students", Journal of Managerial Psychology, Vol. 11 No. 3, pp. 12-25.

Laukkanen, M. (2000), "Exploring alternative approaches in high-level entrepreneurship education: creating micro-mechanisms for endogenous regional growth", Entrepreneurship and Regional Development, Vol. 12 No. 1, pp. 25-47.

Learned, K.E. (1992), "What happened before the organization? A model of organization formation", Entrepreneurship: Theory and Practice, Vol. 17 No. 1, pp. 39-48.

Leroy, H., Maes, J., Sels, L., Debrulle, J. and Meuleman, M. (2009), "Gender effects on entrepreneurial intentions: a TPB multi-group analysis at factor and indicator level”, Paper Presented at the Academy of Management Annual Meeting, Chicago, Illinois.

Linan, F. and Fayolle, A. (2015), "A systematic literature review on entrepreneurial intentions: citation, thematic analyses, and research agenda", The International Entrepreneurship and Management Journal, Vol. 11, pp. 907-933.

Martin, B.C., McNally, J.J. and Kay, M.J. (2013), "Examining the formation of human capital in entrepreneurship: a meta-analysis of entrepreneurship education outcomes", Journal of Business Venturing, Vol. 28, pp. 211-224.

McClelland, D.C. (1961), The Achieving Society, Van Nostrand Reinhold, Princeton, New Jersey.

Mueller, S.L. and Thomas, A.S. (2001), "Culture and entrepreneurial potential: a nine country study of locus of control and innovativeness", Journal of Business Venturing, Vol. 16, pp. 51-75.

Olsen, R.A. and Cox, C.M. (2001), "The influence of gender on the perception and response to investment risk: the case of professional investors", The Journal of Psychology and Financial Markets, Vol. 2 No. 1, pp. 29-36.

ÖSYM (2020), "Yüksek Öğretim Kurulu Öğrenci Seçme ve Yerleştirme Merkezi - student selection and placement center", available at: http://www.osym.gov.tr/TR,12454/2016-osys-yuksekogretimprogramlari-ve-kontenjanlari-kilavuzu.html (accessed 30 March 2020). 
Passaro, R., Quinto, I. and Thomas, A. (2018), "The impact of higher education on entrepreneurial intention and human capital”, Journal of Intellectual Capital, Vol. 19 No. 1, pp. 135-156.

Pfeifer, Sç, Sarlija, N. and Susac, M.Z. (2016), "Shaping the entrepreneurial mindset: entrepreneurial intentions of business students in Coratia", Journal of Small Business Management, Vol. 54 No. 1, pp. 102-117.

Pillis, E. and Reardon, K.K. (2007), "The influence of personality traits and persuasive messages on entrepreneurial intention: a cross-cultural comparison", Career Development International, Vol. 12 No. 4, pp. 382-396.

QS World University Rankings (2020), available at: https://www.topuniversities.com/universityrankings/world-university-rankings/2020 (accessed 30 March 2020).

Rubio, L.E.A., Pozo, C.E. and Agote, M.A.L. (1999), "Actitudes hacia la creación de empresas: un modelo explicativo", Revista Europea de Dirección y Economia de la Empresa, Vol. 8 No. 3, pp. 37-51.

Sexton, D.L. and Bowman-Upton, N. (1990), "Female and male entrepreneurs: psychological characteristics and their role in gender-related discrimination”, Journal of Business Venturing, Vol. 5, pp. 29-36.

Shane, S. (2008), The Illusions of Entrepreneurship: The Costly Myths that Entrepreneurs, Investor, and Policy Makers Live by, Yale University Press, New Haven, Connecticut.

Shapero, A. and Sokol, L. (1982), "The social dimensions of entrepreneurship", in Kent, C., Sexton, D. and Vesper, K. (Eds), Encyclopedia of Entrepreneurship, Prentice Hall, Englewood Cliffs, New Jersey, pp. 72-90.

Shay, J. and Terjesen, S. (2005), "Entrepreneurial aspirations and intentions of business students: a gender perspective", a paper presented at the Babson Entrepreneurship Conference, Boston, MA.

Shinnar, R.S., Hsu, D.K. and Powell, B.C. (2014), "Self-efficacy, entrepreneurial intentions, and gender: assessing the impact of entrepreneurship education longitudinally", International Journal of Management in Education, Vol. 12, pp. 561-570.

Shinnar, R.S., Pruett, M. and Toney, B. (2009), "Entrepreneurship education: attitudes across campus”, The Journal of Education for Business, Vol. 84 No. 3, pp. 151-158.

Sivarajah, K. and Achchuthan, S. (2013), "Entrepreneurial intention among undergraduates: review of literature", European Journal of Business and Management, Vol. 5 No. 5, pp. 172-186.

Slovic, P. (2000), The Perception of Risk, Earthscan Publications, London.

Stewart, W.H., WatsonCarland, W.E.J.C. and Carland, J.W. (1999), "A proclivity or entrepreneurship: a comparison of entrepreneurs, small business owners, and corporate managers", Journal of Business Venturing, Vol. 14 No. 2, pp. 189-214.

Sullivan, D.M. and Meek, W.R. (2012), "Gender and entrepreneurship: a review and process model", Journal of Managerial Psychology, Vol. 27 No. 5, pp. 428-458.

Thomas, A.S. and Mueller, S.L. (2000), "A case for comparative entrepreneurship: assessing the relevance of culture", Journal of International Business Studies, Vol. 31 No. 2, pp. 287-301.

UNCTAD (2004), "Entrepreneurship and economic development: the Empretec showcase", available at: http://www.unctad.org/en/docs/webiteteb20043_en.pdf (accessed 2 February 2017).

Verheul, I., Thurik, R., Grilo, I. and van der Zwan, P. (2012), "Examining preferences and actual involvement in self-employment: gender and the entrepreneurial personality", Journal of Economic Psychology, Vol. 33 No. 2, pp. 325-341.

Wasylow, B., Mellot, R. and Martin, W.E. Jr (2006), "The impact of vocational and personality factors on career development of first-year college students", in Walz, G.R., Bleuer, J.C. and Yep, R.K. (Eds), Vistas: Compelling Perspectives on Counselling 2006, American Counselling Association, Alexandria, VA, pp. 219-222.

Webber, L. (2007), "Firstborns more likely to become entrepreneurs", available at: http://www.inc.com/ nes/articles/200712/oldest_Printer_Friendly.html (accessed 2 May 2009). 
ET

63,5

Wilson, F., Kickul, J. and Marlino, D. (2007), "Gender, entrepreneurial self-efficacy, and entrepreneurial career intentions: implications for entrepreneurship education”, Entrepreneurship: Theory and Practice, Vol. 31, pp. 387-406.

Wilson, F., Marlino, D. and Kickul, J. (2004), "Our entrepreneurial future: examining the diverse attitudes and motivations of teens across gender and ethnic identity", Journal of Developmental Entrepreneurship, Vol. 9, pp. 177-197.

$\mathrm{Wu}, \mathrm{S}$. and Wu, L. (2008), "The impact of higher education on entrepreneurial intentions of university students in China”, Journal of Small Business and Enterprise Development, Vol. 15 No. 4, pp. $752-774$.

Zeffane, R. (2015), "Gender, trust and risk-taking: a literature review and proposed research model", Journal of Enterprising Communities: People and Places in the Global Economy, Vol. 9 No. 3, pp. 221-232.

Zhao, H., Seibert, S.E. and Lumpkin, G.T. (2010), "The relationship of personality to entrepreneurial intentions and personality: a meta-analytic review", Journal of Management, Vol. 36 No. 6 , pp. 381-404.

\title{
Further reading
}

Davey, T., Plewa, C. and Struwig, M. (2011), "Entrepreneurship perceptions and career intentions of international students", Education + Training, Vol. 53 No. 5, pp. 335-352.

\begin{abstract}
About the authors
Eda Gurel is an assistant professor teaching marketing in the Tourism and Hotel Management Department at the Faculty of Applied Sciences, Bilkent University, Turkey. She received her $\mathrm{PhD}$ in business administration from Hacettepe University, Turkey. Her research interests include services marketing, museums, tourism ethics and entrepreneurship. She has published in International Journal of Arts Management, Annals of Tourism Research, European Journal of Marketing and Journal of Business Ethics. She also has national and international patents for her invention titled "System for customized games and routes (tours) for cultural and natural heritage". Eda Gurel is the corresponding author and can be contacted at: eda@tourism.bilkent.edu.tr

Melih Madanoglu is Michael A. Leven Endowed Chair and Professor in Hospitality Management in Coles College of Business at Kennesaw State University, USA. He earned his doctoral degree in hospitality and tourism management from the Pamplin College of Business at Virginia Tech University. His research interests are related to firm performance, risk-return analysis, franchising and entrepreneurship. His work was published in Journal of Retailing, Tourism Management, Small Business Economics, Journal of Business Research, Journal of Small Business Management, International Journal of Hospitality Management and International Journal of Contemporary Hospitality Management.

Levent Altinay is a Professor of Strategy and Entrepreneurship in the Oxford Brookes Business School in the UK. He is the editor-in-chief of the Service Industries Journal. His research interests are entrepreneurship, strategic alliances and international business. He has published in Journal of Business Research, International Small Business Journal, Journal of Small Business Management, Journal of Services Marketing, The Service Industries Journal, Annals of Tourism Research, Tourism Management, Journal of Travel Research and International Journal of Hospitality Management.
\end{abstract}

For instructions on how to order reprints of this article, please visit our website:

www.emeraldgrouppublishing.com/licensing/reprints.htm

Or contact us for further details: permissions@emeraldinsight.com 